\title{
IAMJ
}

INTERNATIONAL

AYURVEDIC

MEDICAL JOURNAL

\section{ROLE OF GUDUCHI IN PREVENTION OF OXIDATIVE STRESS - A REVIEW}

\author{
Suvitha S V', Gayatri², Sarika Yadav³, C. R. Yadav ${ }^{4}$
}

${ }^{1}$ P.G Scholar, P.G Department of Kriya Sharir, National Institute of Ayurveda, deemed to be University(de-novo), Jaipur, Rajasthan, India

${ }^{2}$ P.G Scholar, P.G Department of Kriya Sharir, National Institute of Ayurveda, deemed to be University(de-novo), Jaipur, Rajasthan, India

${ }^{3}$ Assistant professor, P.G Department of Kriya Sharir, National Institute of Ayurveda, deemed to be University(de-novo), Jaipur, Rajasthan, India

${ }^{4}$ Associate professor \& H.O.D, P.G Department of Kriya Sharir, National Institute of Ayurveda, deemed to be University(de-novo), Jaipur, Rajasthan, India

Corresponding Author: svsuvitha92@gmail.com

https://doi.org/10.46607/iamj10p5062021

(Published online: September 2021)

Open Access

(C) International Ayurvedic Medical Journal, India 2021

Article Received: 31/07/2021 - Peer Reviewed: 30/08/2021 - Accepted for Publication: 31/08/2021

\section{ABSTRACT \\ Oxidative stress is a phenomenon that occurs in the body when there is an imbalance between the production of oxygen reactive species (free radical) and antioxidant molecules. Rusting of iron takes place on continuous expo- sure to oxygen. Likewise, the accumulation of free radicals in the body results in oxidative stress which results in tissue damage and thus leads to various diseases. Rasayana Chikitsa helps in the attainment of good quality of rasa. Guduchi [Tinospora cordifolia (Willd) Miers. F. \& Thomas] is a marvellous drug having Rasayana property belonging to the Menispermaceae family enriched with antioxidant molecules. It has the power to detoxify, reju- venate and boost the immune system. 'Guduchi' the word itself conveys the meaning 'which protects the body from diseases. Tinospora cordifolia is well known for its properties such as antioxidant, anti-hyperglycemic, anti- hyperlipidemic, hepato-protective, cardio-protective, neuroprotective, osteo-protective, radio-protective, anti- anxiety, adaptogenic agent, analgesic, anti-inflammatory, antipyretic, thrombolytic agent, anti-diarrheal, anti-}


ulcer, anti-microbial and anti-cancer agent. An attempt has been made to review the role of Guduchi in the prevention of oxidative stress based on the different studies carried out regarding the antioxidant activity of Guduchi. Studies proved that the Phenolic content of Guduchi is meant for its antioxidant activity. Based on Ayurvedic theories, Guduchi acts at the level of Agni and helps in the formation of the fine quality of rasa. Also, prevent the accumulation of a toxic substance called Ama that which is considered as the root cause of disease.

Keywords: Guduchi, free radical, Oxidative stress, Antioxidant activity

\section{INTRODUCTION}

Oxygen is a very essential element needed by body cells for its energy requirements. During the use of oxygen for ATP production, cells release some amount of free radicals. Free radicals are the unstable molecule that steals electrons from other molecules by that damages important cell structures. These free radicals will be neutralized by cells own antioxidant enzymes by that it maintains the homeostasis of the body. But contrary to that, when there is excess production of free radicals body cells won't be able to neutralize it. This ultimately leads to oxidative stress. Oxidative stress is defined as excess production of Reactive Oxygen Species (ROS) relative to antioxidant defences. Reactive oxygen species are generated as a metabolic by-product by a biological system such as superoxide radicals, hydrogen peroxide, hydroxyl radicals and singlet oxygen. When free radical production got increases, it starts shows harmful effects on important cellular structures like proteins, lipids and nucleic acid. Oxidative stress is responsible for the onset and progression of various diseases such as diabetes, hypertension, cancer, metabolic disorder and cardiovascular disorder etc. To prevent oxidative stress, it's very essential to make sure of getting enough antioxidants in our diet. Antioxidants are substances that prevent oxidative stress by donating electrons to free radicals. Rasayana is a special branch of Ayurveda that helps to detoxify the body and also revitalize and nourishes the body. Rasayana makes the individual stay healthy due to its magical qualities of medicinal herbs such as immunomodulatory, adaptogenic, antioxidant, nootropic and anti-stress. Guduchi is a well-known Rasayana drug having synonym as Rasayani, Charaka emphasized it under Medya Rasayana ${ }^{l}$. Guduchi is having properties like
Tridoshahara, Vayasthapan, Triptighna, Dahaprashaman, Stanyashodhan, etc. Various research works have been carried out on the antioxidant activity of Guduchi and showed significant results too. This review study article helps to evaluate the antioxidant activity of Guduchi and its role in cut down various diseases by preventing oxidative stress.

MATERIALS AND METHOD: Study materials are collected from various classical ayurvedic texts and modern textbooks, international journals, internet sites and also research articles related to this subject.

\section{OXIDATIVE STRESS}

Oxidation is a very essential process taking place in every cell of our body during energy production. Moreover, oxidative-mediated reactions are involved in many fundamental aspects of life processes such as cell respiration, lipid synthesis, metal metabolism, lysosomes, phagocytosis of foreign bodies, and xenobiotic biotransformation of organic compounds. Free radicals are highly reactive and unstable molecules that are released by mitochondria during energy production. Also, ROS will be produced in the body by exposure to toxins in the environment such as tobacco smoke and ultraviolet light. There are many different varieties of partially reduced reactive oxygen species (ROS) including superoxide $\left(\mathrm{O}_{2}^{-}\right)$, hydrogen peroxide $\left(\mathrm{H}_{2} \mathrm{O}_{2}\right)$, and the hydroxyl radical $\left(\mathrm{OH}^{-}\right)$. Free radicals have a lifespan of only a fraction of a second, but during that time they can damage DNA, sometimes resulting in mutations that can lead to cancer. Free radicals are oxygen-containing elements with an uneven number of electrons. The uneven number of electrons in free radicals allows them to easily react with other molecules. At the same time, cells produce natural antioxidant enzymes to balance the free radi- 
cals. Over accumulation of reactive oxygen species in the body ultimately leads to oxidative stress. Oxidative stress arises when there is an imbalance between free radicals and free radical scavenging molecules. The increased oxidative stress is due to intake of diet rich in fat, sugar, processed food, alcohol consumption, smoking, stress etc. Oxidative stress leads to premature ageing, wrinkles in the skin, poor vision and various lifestyle disorders that account for around $70 \%$ of death worldwide according to a WHO report.

\section{RASAYANA CHIKITSA}

Rasayana is a time old concept and mentioned under one among eight branches of Ayurveda. The ultimate aim is to maintain the health of a healthy individual and the disease of the diseased person. All bodily tissues are getting nourished from Ahara Rasa. Rasayana therapy helps in the formation of the best quality of rasa. Consequently, Rasayana helps in the regeneration, revival and revitalisation of all body tissues. Oxidative stress is considered the root cause of various metabolic disorders. Rasayana therapy helps in overcoming oxidative injury. Guduchi is a Rasayana drug highlighted under Medhya Rasayana.

\section{GUDUCHI}

Botanical name: Tinospora cordifolia (Willd) Miersex Hook. F \& Thomas.

Family: Menispermaceae $\quad($ Mene $=$ moon and sperm=seed)

The plant belongs to this family have moon-shaped seeds

\section{Historical background of origin}

Ravana, the king of Lanka overcome with lust, kidnapped Sita the wife of Rama, then the mighty Rama assisted by the army of monkeys fought Ravana and killed him on the battlefield, Lord Indra got greatly pleased at the death of Ravana the enemy of gods, the monkeys who killed by the demons were rendered alive, by sprinkling nectar on them. In all places where drops of nector fell on the ground running from the bodies of monkeys, there grew the plant of Guduci ${ }^{2}$.

\section{Botanical Description}

Tinospora cordifolia is a large, glabrous and climbing succulent perennial shrub with rocky bark. Leaves are petioled, membranous and cordate with broad sinus and $5.0-10.0 \mathrm{~cm}$ blade. Tinospora cordifolia found throughout tropical India. The flowers are small, yellow and unisexual. Male flowers are fascicled, and females are usually solitary. Drupes, the fruits are ovoid, succulent, lustrous and red when ripe. Seeds are curved.

\section{Synonyms}

Guduchi, Madhuparni, Amrita, Amritavalli, Chhina, Chhinaruha, Chinnodbhava, Vatsadani, Jivanti, Tantrika, Soma, Somavalli, Kundali, Cakralaksanika, Dhira, Vishalya, Rasayani, Chandrahasa, Vayastha, Mandala, Devanirmita. ${ }^{3}$

The word 'Guduchi' meaning "that which protect the body from diseases ${ }^{4}$ ". Also, it has a synonym as amrita because it gives longevity as nectar.

\section{Rasa Panchaka}

Rasa: Tikta, Kashaya, Katu, Guna: Laghu, Virya: Usna, Vipaka: Madhura

Karma: Tridoshahar, Rasayana, Sangrahi, Agnivardhaka, Balya ${ }^{6}$, Stanya Shodhan, Rakta Shodhana, Vishaghna etc.

\section{CHEMICAL CONSTITUENTS}

Tinosporine, tinosporon, tinosporic acid, tinosporol, tinosporide, tinosporidine, columbin, chasmanthin, palmarin, berberine, giloin, giloinisin, 1, 2-substituted pyrrolidine, a diterpenoid furanolactone, 18norclerodanediterpene-O-glucoside, aryltetrahydrofuranolignan, octacosanol, nonacosan-IS-one and sitosterol, cordifolide, unosporin, heptacosanol, cordifol. Cordifolon, magnoflorine, tembetarine, cardiofoliosides A \& B. phenolic lignan- 3-(,4-dihydroxy-3 methoxybenzyl)-4-(4-hydroxy-3-methoxybenzyl) tetrahydrofuran, arabinogalactan (various parts) Giloin, Giloinin, Gilosterol, Berberine. ${ }^{7}$

\section{FREE RADICAL VS AMA}

Free radical is the end product of the oxidative reaction in our body. Accumulation of more free radicals end up with toxicity and produce more metabolic disorders such as hypertension, diabetes etc. In Ayurve$d a$, free radicals can be correlated with Ama. Ama accumulation in the body favours the formation of disease in the body. Wherever Ama goes and settles, there it produces disease also ${ }^{8}$. When digestive fire 
(Agni) gets weak, food enters into stomach won't get digested and forms a toxic substance called $A m a^{9}$. According to Ayurveda, Ama and Mandagni ${ }^{10}$ is considered the root cause of all diseases. When Ama is found at the level of the digestive tract we can easily clear it out but once it pervaded into deep tissues, it becomes more difficult to eliminate it. Ama gets accumulated in channels of the body and disrupts tissue nutrition. It affects physiological processes at the cellular level also.

\section{DISCUSSION}

\section{ROLE OF GUDUCHI IN PREVENTION OF OX-} IDATIVE STRESS

Guduchi is an effective Rasayana drug mentioned under Medhya Rasayana as Churna Kalpana. Properties of Guduchi includes Tridoshahar, Balya, Jwaraghni, Vishagni and Agnivardhaka. Rasayana therapy helps one to get good quality of Rasa, Raktadi Dhatus. Ahara Rasa is known to be the premier nutrition of the body tissues, hence it is counted as a precursor of all tissues. Both qualitative and quantitative normalcy of rasa is considered as the normalcy of health. Ama accumulation of body is considered as the root cause of all disease whereas in modern science oxidative stress takes place because of accumulation of free radicals resulting in various diseases by damaging important cellular structures. Guduchi acts at the level of Agni, rasa and Srotas. Rasa of Guduchi is Tikta. Vayu and Aakash Mahabhuta is predominant in Tikta Rasa ${ }^{11}$. Due to its Laghu Guna, it promotes digestive fire and does Ama Pachana, that act as a great preventive measure for various diseases. Dosha, Dhatu and Mala is considered as the root of the body $^{12}$. By Tridoshahar property, it maintains the equilibrium of Doshas. By Agnivardhaka and Balya property, Guduchi helps in the formation of good quality of rasa, clears out the toxins accumulated in Srotas and do Dhatu Poshan.

Various studies have been carried out on the Antioxidant activity of Tinospora cordifolia. The chemical constituents reported from this shrub belong to different classes such as alkaloids, diterpenoid lactones, glycosides, steroids, sesquiterpenoid, phenolics, aliphatic compounds and polysaccharides ${ }^{13}$. Antioxidant activity was assessed by DPPH (1, 1-Diphenyl-2picrylhydrazyl), total reducing power, Total polyphenolic content, Hydrogen peroxide scavenging activity assay, Hydroxyl radical scavenging activity. Studies find out the Phenolic content of Tinospora cordifolia is mainly responsible for antioxidant activity ${ }^{14}$. Phenolic compounds can inhibit free radicals by donating hydrogen atoms from hydroxyl group or by chelating metal ions such as iron and copper, also by inhibiting the oxidation of low-density lipoproteins (LDL). By that, administration of drug Guduchi helps in preventing oxidative stress shown in Fig 1.

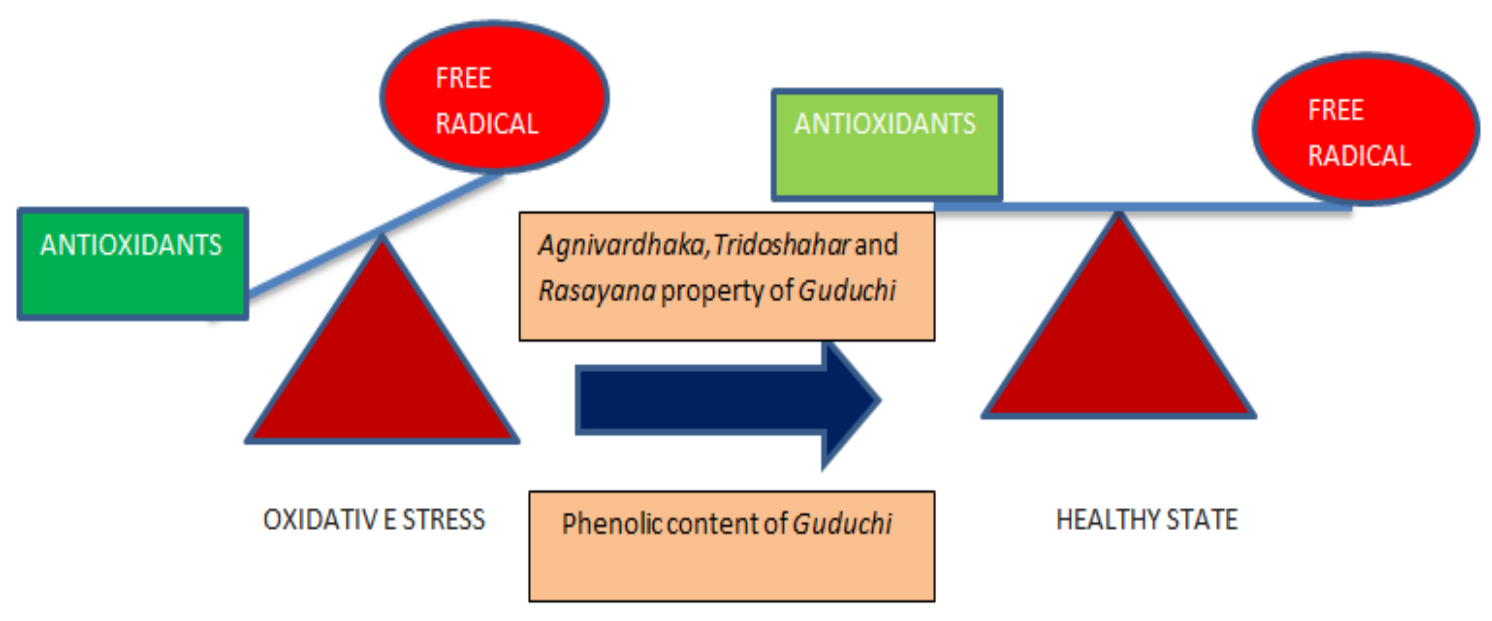

$\{$ Fig-1\} 


\section{CONCLUSION}

Nowadays, due to unhealthy lifestyles and mental stress, the body is more viable to oxidative stress. Oxidative stress damages important cellular structures and makes the body more prone to various metabolic disorders. Metabolic disorders are considered a great burden to socioeconomic development in developing countries. Rasayana is the uniqueness of Ayurveda mainly stress on better health and prevention of disease. It's better to start with prevention as it cost less in lives and dollars. Oxidative stress can be prevented by maintaining the antioxidant level in the body. Guduchi is a marvellous Rasayana drug that cut down the progress of pathogenesis due to its $A g$ nivardhaka, Amapachana qualities and is loaded with antioxidant properties. Research proved that the phenolic content of Guduchi is responsible for antioxidant activity. So as a part of Vatatapika Rasayana, Guduchi is strongly recommended in the prevention of oxidative stress.

\section{REFERENCES}

1. Agnivesha; Charaka Samhita revised by Charaka and Dridhabala with Ayurveda Dipika commentary by Chakrapanidatta edited by Vaidya Jadavaji Trikamji Acharya, Chaukhambha Orientalia, Varanasi, Reprint Edition 2015, chikitsa Sthana ch.1:3/30, Page no. 385

2. Ibid B.P.Pu ch.6/1-5 page no 228

3. Ibid B.P.Pu ch.6/6-8 page no 228

4. Priya vrat Sharma;namarupavijnanam characterization of medicinal plants based on the etymological derivation of names and synonyms, chaukhambha visvabharati, Satya Priya Varanasi, page no:75

5. Bhavamisra; Bhavaprakasha Samhita including Nighantu Portion with text, English Translation, notes, appendices, and index translated by Prof. K.R. Srikantha Murthy, Volume 1, Krishnadas Academy, Varanasi, First Edition 1995, Purvakhanda 6/9,10 page no 228

6. Ibid B.P.Pu ch.6/1-5 page no 228

7. Amirta for life Tinospora cordifolia (Giloy), National medicinal plant board, Ministry of Ayush Government of India, page no 11

8. Sushruta; Sushruta Samhita with Nibandha Sangraha Commentary by Sri Dalhana Acharya and Nyayachandrika Panjika commentary on Nidana Sthana by
Sri Gayadasa Acharya edited by Vaidya Jadavaji Trikamji Acharya, Chaukhambha Orientalia, Varanasi, Reprint Edition 2019, Uttara Sthana 56/3, pg.no 781

9. Vagbhata; Ashtanga Hridaya, Sarvanga Sundra and Ayurveda Rasayana commentary by Arundatta and Hemadri edited by Bhisagacharya Hari Sastri Paradakara Vaidya, Chaukhambha Orientalia, Varanasi, Reprint 10th Edition 2019, Sutra Sthana 13/25 page no 216

10. Vagbhata; Ashtanga Hridaya, Sarvanga Sundra and Ayurveda Rasayana commentary by Arundatta and Hemadri edited by Bhisagacharya Hari Sastri Paradakara Vaidya, Chaukhambha Orientalia, Varanasi, Reprint 10th Edition 2019, Nidana Sthana 12/1, Page no513

11. Ibid AH.Su.ch.10/1 page no 174

12. Ibid AH.Su.ch.11/1 page no 182

13. http://medind.nic.in/ibi/t03/i2/ibit03i2p83.pdf

14. Neha Upadhyay, Showkat Ahmad Ganie, Rajneesh K Agnihotri, Rajendra Sharma, Studies on Antioxidant Activity and Total Phenolic Content of Tinospora cordifolia (Miers.) Stem Using in Vitro Models. American Journal of Phytomedicine and Clinical Therapeutics, AJPCT [1][8][2013]617-627

\section{Source of Support: Nil Conflict of Interest: None Declared}

How to cite this URL: Suvitha S V et al: Role Of Guduchi In Prevention Of Oxidative Stress - A Review. International Ayurvedic Medical Journal \{online\} 2021 \{cited September 2021\} Available from: http://www.iamj.in/posts/images/upload/3113_3117.pdf 